\title{
Community Development through Hydroelectric Project: A Case Study of Gilgel Gibe III Hydroelectric Power Project in Ethiopia
}

\author{
Aklilu Kahssay and Sanjay Mishra \\ Department of Sociology, Mekelle University, Ethiopia
}

\begin{abstract}
Ethiopia is a country where over $90 \%$ energy demand is supplied through traditional sources with over use and extinction of natural and traditional sources exploring new sources are the compulsion of the economy. Simultaneously, with rising population industrial activities are also increasing which propel the energy demand. The objective of the article is to seek out the impacts of the Gilgel Gibe III hydro power project on the community development. Taking integrated approach several important factors concerning to community development have been investigated such as health, ecology and environment, employment opportunities and its impact on income dynamics, infrastructure. In the study efforts also have been made to know the impacts on cultural, religious, historical and archeological sites. The study is mainly based on secondary data. However to support the work some primary data through local residents and the university students were also taken. Informal discussion with the officials involved in the project and local people around the Omo river valley, the project sites also have been held to know their personal opinion and expectations from the project. The analysis of the available data reveals that the project has positive impact on the community development. It concludes that the project might be a milestone for the community development, and benefits for the people living in the region. With commencement of the project, economic activities in the region have already been started and providing several non-traditional business opportunities which opens new opportunities of employment. Moreover the change due to hydroelectric project is expected to transform the communalities with measurable impact. The project has a multidimensional role to play in the development at various levels - community, regional as well as national.
\end{abstract}

Key Words: Community development, displacement, energy, migration, flood, cultivation, rural economy

\section{Introduction}

"Africa is in the dark. Give us a choice. Should we stay in darkness?"Mihert Debeba, Director of the Ethiopia Electricity Corporation (BBC March, 2009).

Community development process has never been equal through the societies perhaps that are the reason why there is a huge difference in the society. Poverty or prosperity decides at large the technology a country opts for the development. Earlier, before the industrialization countries all over world have been depending on the traditional sources of energy for their development. But industrialization has changed the whole concept of the development. Now development process depends completely on the potential to exploit the natural resources by the advancement of technology and making technology inroad into the community.

Energy production and consumption undoubtedly is one of the most apparent parameter of the economic development and poverty alleviation for any country (Modi et al., 2006; Saghir, 2005). In subSaharan Africa access to electricity by the population is still very low due to lack of technology and inefficiency to utilize the natural resources. Ethiopia is not an exception; it also is like other sub-Saharan countries where access to grid is very poor despite having equipped with considerably rich natural resources especially the water resource; but untapped at large, due to several reasons including technological inefficiency, resource management and utilization, which has been the most important hurdle in the economic developments. Somehow urban population is access to the electricity up to a certain extent but the situation is much worse in the rural area, only about $30.5 \%$ population across region is access to electricity, while it is only $14.2 \%$ in the rural areas (International Energy Agency, 2009). In comparison to Sub-Saharan African countries access to the electricity Ethiopia is still very low. According to International Energy Agency (IEA), national electricity access is estimated to be at $17 \%$ in 2009 and $15 \%$ in 2008 ; of which only $2 \%$ goes to rural areas (IEA, 2009). However, per capita consumption of electricity remains very low at about $200 \mathrm{kwh}$ per year (World Bank, 2012).

Due to unreliable grid supply most of the households across the region depend on candles, biomass, and other non-electric sources for their lighting needs. And cow dung, weeds, agricultural wastes, jungle woods and other alternative sources are used to obtain energy for cooking meals. These 
fuel- based lighting sources generate poor quality light with very low efficiencies (Dutt, 1994; Mills, 2005; Van der Plas and de Graaff, 1988). Women and children are worst sufferers of the system; in majority of households, women are responsible to collect fuel through various sources, in doing so they have to travel on foot for long distances (Batliwala, Reddy 2003; Laxmi et al., 2003). Also, fuel based energy used for lighting and cooking is associated with soot indoor air pollution (Mishra, 1999; Peon et al., 2005) which may cause to several diseases related with respiratory system and eye irritation. With initiation of various educational projects, now Ethiopia is well on track to exploit the natural as well as human resources by producing the indigenous scientists and engineers. The successful initiation of the hydroelectric project may also contribute in obtaining the Millennium Development Goal $^{1}$ (MDG), Millennium Village Project (MVP) started in 2004 which currently covers about 400,000 people in 80 millennium villages across $10 \mathrm{Sub}$ Saharan countries (Sanchez et al, 2007, Sanchez et al, 2009).

In process to resource utilization the Government commenced an ambitious hydroelectric power project on the Omo River, which is partly based on marketing. Produced energy will be supplied to the neighboring countries. Mainly, due to the availability of the least-cost vast resource, the country's electricity has been predominantly supplied from the hydro since the 1970s (Almaz, 2005).

Primary indicators reflect that if the project successfully completed and marketing plan implemented, Ethiopia can be counted as the one of the leading energy exporter countries of the continent. Hydroelectric power projects have successfully catered the energy needs of the many emerging economies of the world, due to low cost of power production. The project is very important in many ways first - people living in the area where power project is continued are reasonably low income with traditional agriculture and pastoral system thus, living miserably. Secondly, the project would provide an opportunity to utilize the natural resources which was unused. Simply the energy consumption rate is very low in Ethiopia, and that too, of the total energy consumption about $96 \%$ comes from the traditional sources. According to the state owned Ethiopian Electric Power Company, other than low-cost electricity, there are no ways of improving the living conditions and daily routine of so many people so quickly and dramatically in Ethiopia (EEPCo / EMU, 2009). In such a situation, energy production and consumption is required to increase to pave the country to the path of development. The article efforts to analyze the project and throws a light on how it can overall implicate the population and thrust the process of development.

Omo-Gibe basin is one of the significant surface water resources of Ethiopia, which has been considered as one of the potential area for hydroelectric development. Gilgel Gibe I and Gibe II hydroelectric dams have already been constructed and are operational on the main Gibe/Omo River. The Gibe III Hydropower Project is an extension of Gilgel Gibe I and Gibe II. The ongoing energy project is set to be the second largest source of hydroelectric power of Ethiopia after the Great Grand Renaissance Dam on Nile River. The paper is focused on a critical appraisal of the project on community development using all recent available reports from various sources.

\section{Objectives}

The objective of this study is to describe and evaluate socio- economic impacts of the Gilgel Gibe III hydroelectric project on community development in Southern Ethiopia, which are as under:

-To seek out the overall impact of the project on the economic activities in the area and how it can open the new avenues for the employment as well other sources of the income generation activities.

- To seek out whether considerable arrangements have been made under existing constitutional safety nets, and how it can ensure the participation of marginalized/poor people in the process.

-To examine the potential ecological impacts, in terms of people their livelihood opportunities, agricultural prospects and wild life preservation including all sorts of forest dwellers

-In the last, it looks at how it will impact the regional integration within Ethiopia and across the horn of Africa.

\section{Literature Review}

Rodrigue and Comtois (2013) in their study state that there is a close correlation between the use of energy and the quality of life. In line with this Najam and Cleveland, (2008) finds that access to sustainable energy is a key factor for promoting social progress and economic growth - both of which are closely linked to sustainable poverty reduction. Roger (2008) finds an observable links between energy and gross domestic product (GDP); he states that there is a straight correlation with energy usage and economic growth. Therefore, he argued energy per capita usage is now days perceived as one of the indicator of sustainable development. Najam and Cleveland (2008) on the other hand also find observable linkage 
between energy and the social dimension of the sustainable development. Energy is absolutely essential to deliver adequate services, food, water, health care, education, shelter, and employment.

Smil (2007) in his study finds different dimension and patterns of energy use. He examines general patterns, trends, and socioeconomic consideration of energy use today, looking at correlation between energy and value, energy and the economy, energy and quality of life and energy futures. Smil chooses to emphases the complexities and peculiarities of the real world, and the counterintuitive outcomes of many of its processes, over abstract models. Further, he analyzes the sources of energy on all important energy matters, from natural to industrial energy flows, from fuel to food, from the earth's formation to possible energy futures.

In another study Smil (2003) analyzed the major energy sources, storages, flows and conversions that shaped the evolution of the biosphere and civilization. He emphasizes the complexities and peculiarities of the real world, and the counterintuitive outcomes of many of its processes, over abstract models. Further, he criticizes the over use of fossil fuels and their impact on global warming and he counts about the threat facing the planet from fossil fuels, though unsure about what energy policy options ought to be pursued.

Dams' construction has existed for thousands of years for various purposes such as irrigation and flood-control. In the 19th century, dam constructions began to be used for hydroelectricity, and by the 20th century, they had become a mainstay of electricity generation. According to the World Commission on Hydropower Dams(WCD, 2005) hydroelectric power, mostly from dams, supplied $19 \%$ of the world's electricity, more than $90 \%$ electricity supply of 24 countries and cover over $63 \%$ of renewable energy (Energy consumers edge, 2007). World Energy Council (2010) sated that Hydropower have a capacity to supply $50 \%$ all global electricity demands.

Lioney (1995) in his study suggests that the concept of community appears exhibit significance and measurable increase in social pathology, consistent with the conceit of community trauma. Cernea (2004) noted that the inflow of construction workers which he called it" "Boomtown effects" to traditional and remote local communities causes health problems notably the spread of sexual transmitted diseases including HIV/AIDS and cultural problems at the local community level. World Commission (2000) on Dams stressed the importance of strategic assessments to minimize the environmental and social impacts of new dams. The substantial size of some hydroelectric projects and the extensive total surface area covered by reservoirs, buildings, offices, power transforming systems and other residential area adjacent to the projects globally require that research determining the impacts of these developments be done at various levels such as community as well as socio-economic impacts level. As a consequence of this research, new views are emerging about the socio-economic extent and longevity of the environmental and social impacts of such developments (Rosenberg and et al., 1997). Valuable cultural assets of underground remaining cultural sites and other buildings may be lost due to dam constructions (Cernea, 2004).

\section{The Study Area}

The study area is located in the Southern Nations, Nationalities and Peoples of Ethiopia. The Gibe III hydroelectric is located within the Omo Gibe River basin in the middle reach of the Omo River, around $450 \mathrm{~km}$ by road South of Addis Ababa. The scheme, from the root of its reservoir to its tailrace outfall, extends over a corridor some $155 \mathrm{~km}$ long. Administratively, the reservoir stretches over five zones $^{2}$, eleven Weredas ${ }^{3}$ and 67 kebeles $^{4}$. However, all the works concerning the construction of the Gibe III scheme dam, tunnel, power house, switchyard, construction camps and access road are concentrated in area under the jurisdiction of the Loma Wereda of the Dawro Zone and Kindo Didaye and Kindo Koysha weredas of Wolayta zone of the Southern Nations and Nationalities People Regional State (EEPCo/RAP, 2009).

The project area is characterized by a great deal of ethnic and religious diversity. More than 13 different ethnic groups including the Wolita, Dasenech, Karo, Hamer, Mursi, Murle, Mugugi and Nyangatom live in the project area (Anaya, 2010; RAP, 2009). The major ethnic group in the project affected Woreda is Wolita $(95 \%)$ and others 5\% (EEPCo/RAP, 2009). Around Omo river valley and Lake Turkana area an estimated population is over 170,000 and it is remarkable to mention here that the population is likely to double after every 20 years (Avery, 2012). According estimation over 500,000 people will be directly or indirectly affected by the Gibe III hydroelectric dam (Avery, 2012).

These people have a complex land management system and resource use practices adapted to the harsh conditions of the region (Anaya, 2010), but living in extremely poverty stricken. For their subsistence, they rely on Omo River and for very optimum things such as for grazing and watering livestock, which produce blood, milk, and meat for subsistence as well as income, and their geographical area is semi-arid (Anaya, 2010). 
The Construction of the Gibe III Hydroelectric Project begun in January 2006 and still it is in process. The Gibe III Hydroelectric Project comprises a 230 meter high dam and will create a huge reservoir with a surface area of some $200 \mathrm{~km}^{2}$ and a total storage of some 11,750 million $\mathrm{m}^{3}$. The total cost estimated for the construction of the project is about 1.7 billon US dollar (EEPCo /EMU, 2009; IR, 2010).
The Gibe III project will be the second largest hydroelectric project ever undertaken in the country and it is argued to generate about $1870 \mathrm{MW}$ and $6,400 \mathrm{GWh}$ of firm energy per year. Location coordinates are at 6.84722 latitude and 37.3014 longitudes. The hydroelectric project will generate a capacity of 1870 MWe and located $55 \mathrm{~km}$ downstream of the Gilgel Gibe II Powerhouse (Global energy observatory, 2012).

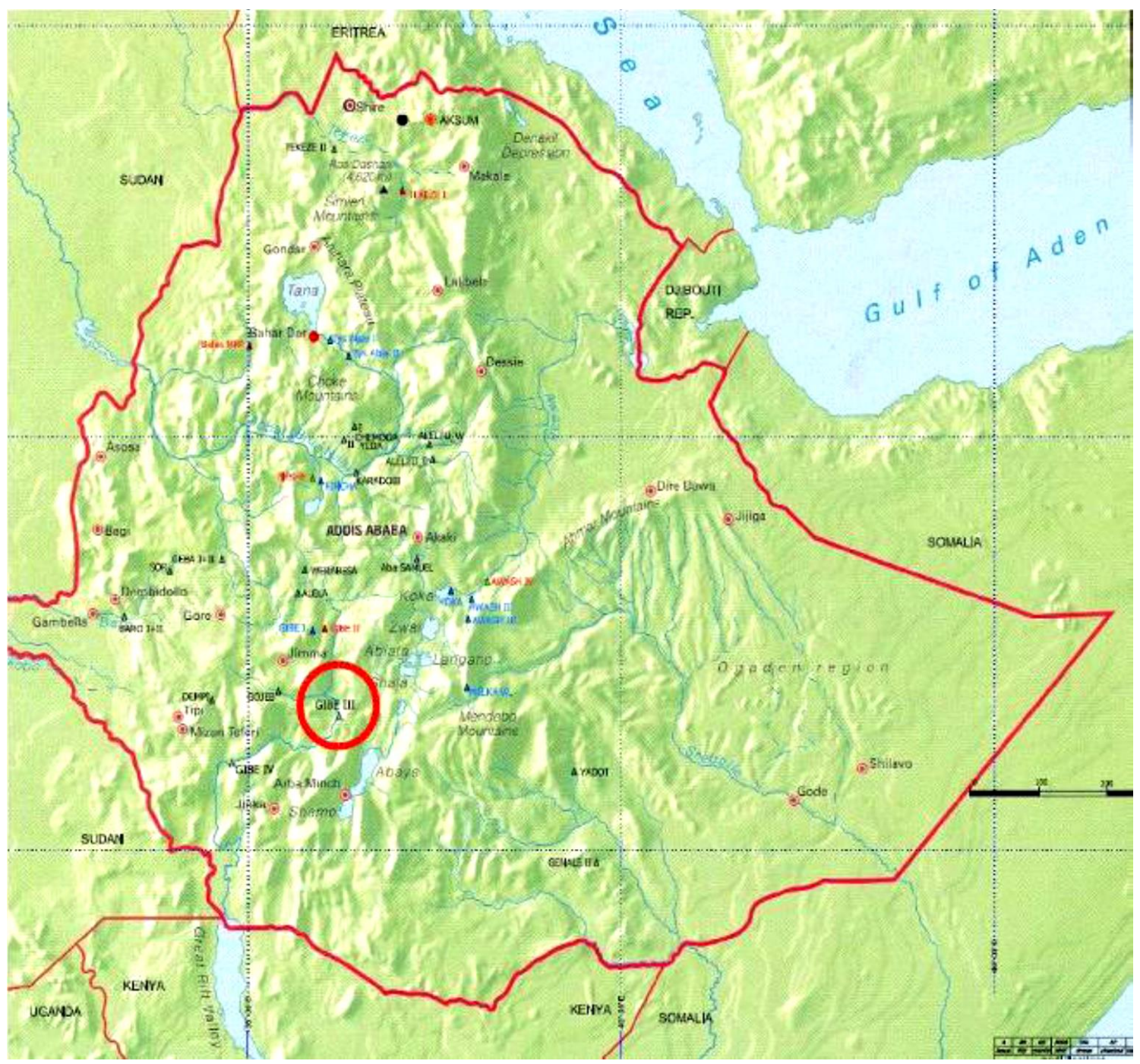

Figure 1. Gibe III project site location Map. Source: Gibe III Ethiopian Electric Power Corporation's Environmental Monitoring Unit (EMU) 


\section{Methodology}

The study is based on secondary data which includes all recent available reports from various sources such as periodicals, journals, media reports, official reports of the Ethiopian government, consultancy agencies involved and their reports, their websites. Informal discussions in various sessions with people either involved in the project or influenced by the project have been held. For Investigation, integrated approach was adopted to estimate the impact of various apparent indicators.

We collected information on existing and proposed hydroelectric dams from the following sources: (1) directly from government ministries following official information requests, and

publicly available government reports. We submitted official data requests to the appropriate governmental ministry during 2010 , and then followed-up on those requests until receipt of the data. Location, project status (existing or planned), and total power production (in megawatts) were identified and discussed as major part of the work. Contacting to the government and other associated officials during the work hours was a difficult task, in case if they were available hesitating to speak on the project, but somehow the researchers managed to access the information. (3) available on websites, consultant's and NGO reports, journals, periodicals research reports and reputed international organizations such as UNESCO, World Bank, UN Millennium Project, UNDP etc. (4) Ultimately to know the opinion of young and educated people' apart from local people, 11 students from the Gilgel Gibe area studying at the Mekelle University were also invited for an informal discussion on the impact and expectation of the project.

Descriptive analyses have been made based on the situation of the available reports. All reports were classified and analyzed accordingly under different sections and heads. Emphases were made to cover equally all the parts of the project and their impacts on the people and area.

\section{Findings}

In this section the major findings with appropriate discussion have been arranged related to people and the project specifically about socio-economic impact on community development, impacts on environments and natural resources, constitutional safeguards and all other associated impacts and indicators. To make the study clear the major findings have been divided into three parts, which are as following:

\section{Socio-economic impact on community development}

This portion covers with various concerns which have apparent influence on the community development.

Public consultations and local participation

Various international laws signed by Ethiopia and its national laws, Policy, Rule and Regulations dictate the need to make public consultation and participation as an integral part of any environmental impact assessments or public affairs. Public opinion is most important essence of the democracy. Ethiopian constitution article 92 in this regard states clearly that "People have the right to full consultation and to expression of their views in planning and implementation of environmental policies and projects that affect them directly." Therefore, people and their opinion are always respected under the project, in case if something could not be covered there are agencies which will work as watchdog for the project.

According the existing Ethiopian legal framework there is enough provision to take care of each and every sort of such allegations. The environmental policy of Ethiopia makes public consultation and participation compulsory before any developmental intervention. Similar policy, followed with the partners involved with the Gilgel Gibe III project such as African Development Bank, European Investment Bank and the World Bank (EEPCo/Gibe III - PC, 2009).The Gibe III official resettlement action plan revealed that a total of 24 consultations were held with more than 455 project affected people, communities and local officials from the project area. This includes 12 consultations with project affected people and community focus groups and another 12 consultations with local officials at wereda as well as kebele levels (EEPCo/ Gibe III RAP, 2009).

The Gibe III Public Consultation and Disclosure Plan document of the government (EEPCo, 2009) also states that in the years 2006, 2007 and 2008 consultative meetings with a total of 1,749 people (1278 community members were from 80 kebele administrations) drawn from different demographic characteristics different stakeholders including from all different levels of governmental offices, NGOs, Peasant associations, local residents, household heads, and from the project client and contractors were involved. For this reason, the report indicated these consultations provided a wider opportunity to gather satisfactory information about the attitudes of the people towards the implementation and the consequences of the project. 
Key agenda points, that were covered during public consultations included impacts of the project ,both positive and negative about the project affected people and local community members, issues regarding property registration and valuation for compensation, cut-off-date, presentation and discussion of compensation options and choices available to project affected people, and availability of skills and opportunities for participation in income and livelihood restoration schemes (EEPCo/RAP, 2009). Friends of Lake Turkana in this regard stated that the majority of project-affected people located downstream of the dam site in the Lower Omo Valley and around Lake Turkana, are politically and geographically marginalized and only a small number of people, about 93 members, attended the public consultation sessions prepared by Ethiopian government. Whereas this statement looks biased as the people of the valley are already at risk due to lack of livelihood opportunities, and also the area and people are cut off from the mainland due to remote locations, therefore it is expected that people of the area will be benefitted this part further have been discussed in next section of the article.

\section{Benefit to the local community}

According to the Gibe III Public Consultation and Disclosure Plan Document of the government (EEPCo, 2009) the consulted community members have been already identified for the benefit of the project. The people have already been benefitting from the project, with its commencement in several forms such as by generating employment opportunities during the construction and in the form of off-the-farm employment opportunities and development in different sectors including revolutionizing the commercial and trade industry during the operation of the project (EEPCo-PCP, 2009). The initial personnel requirement during construction was approximately 1,200 , while at peak construction periods approximately 5,000 personnel which are already recruited to be employed from the local areas on the project. Out of this, around 1000 from the administration and the rest 4000 are semiskilled and unskilled workers (Gibe III Environmental and Social Management Plan, 2009).

The Gibe III Public Consultation and Disclosure Plan Document (EEPCo, 2009) in this regard also indicates that there are opportunity for additional income through provision of services for labor force working on the project such as the sales of local food, beverages and provision of accommodations for migrant workers and the subsequent cultural development as the result of social interactions among migrant workers and the local people.
Besides, the document depict that the project will create a reservoir of 20,000 ha in area and 240 meter deep at the dam Site. This is a large artificial lake that provides different environmental and ecological niches for diverse fisheries and crocodile development farming, recreation establishments, irrigation development plans and navigation which might straight benefit to the neighboring communities during market days and other social occasions. On the other hand, the development of infrastructures also is the probable economic benefits of the project in enhancing trade and commerce among the local communities (Gibe III- ESIA, 2009). From the point of establishing good ties with the communities of the neighboring countries, the document stated that the consulted community members were acknowledged regarding the role of exporting electricity generated from Gibe III project as a means of enhancing strong relationship and other benefits (EEPCo/RAP, 2009). Thus, hopefully change the lives of the people around the area.

It is expected that by generating power the most beneficiary groups are the women because the electricity may provide them opportunity to replace the traditional sources of energy. Traditionally, collecting firewood, bringing water for animal and household consumption are the prime responsibility of the women other than working household chorus. Henceforth, the project may provide extra time for the women to take care of them and their children along with lessening the labor.

Access to substantial amount of water and energy may contribute positively for health and well being among the women groups' in particular and other people in general. Therefore, great advantages for women and the whole society at large (EEPCo/PC, 2009). It is, therefore, expected to revolutionize the process of developments. Earlier studies suggest that energy is the prime thrust for the process of all sorts of development economic as well as social; along with this, the process of the development can be made as sustainable by coordination with local available natural resources. The downstream project area is often prone to the flood. For example, in 2006, the area was heavily flooded which caused the lives of hundreds of people, thousands of animals and over 15,000 people were displaced. Along with this, loss of thousands of Birr of crops and many people lost their livelihood. So, it is expected that such kind natural calamity can be avoided by the project (EEPCo, ESIA, 2009).

Displacement of local people

There is substantial arrangement for the people who are likely to be displaced due to project construction. 
Though, many acres of land are expected to be lost after the reservoir fills with water. As a result, hydroelectric dam constructions often displace former residents which frequently costly in terms of disrupting their economic productivity and causing unemployment. It also comes to great emotional cost to the displaced (Mc Cull, 2003).Thus, rehabilitation and resettlement due to project affected people is another major great economic cost. Though, it is challenging but viable, if once the marketing of the electricity are successfully commenced. But, inefficient planning and implementation may create poor resettlement and rehabilitation process, thereby; further may affect the local people if not tackled efficiently.

Resettlement action plan (RAP) document of EEPCo (2009) estimates that about 2,000,000 people are spread all over area, of which about $11 \%$ of the population might be affected by the project in some or the other ways. However, according the estimation of Avery (2012) over 500,000 people will be directly or indirectly affected by the Gibe III hydroelectric dam. Further, the RAP document indicates that the project area is known for its high population density and the small land holding size. Majority of population are peasants and peasantry is existing system for the mode of production and income. Though, there is huge livelihood diversification which includes agriculture (crop cultivation or laborers and animal rearing) as a base livelihood activity, and also some of them are engaged in wide range of non- farm economic activities such as small scale trade, artisan, handicrafts, and casual labor earning.

The Gibe III project, which is one of the largest hydroelectric projects ever undertaken in the country, expected to displace and affect a number of people. For example the building of Gilgel Gibe I reservoir was reported to displace about 10,000 people (CRBM, 2008). The Gibe III RAP, volume I (2009), however, stated that since the reservoir area of Gibe III is confined within the gorge of the river far from large population settlement areas and hence, only few people are expected to be affected. The document, nevertheless, does not mention the exact number of displaced people due to reservoir and transmission line constructions.

As, it is stated in the Gibe III -ESIS, the reservoir project area affects a total of 355 households, about 188.94 hectares of privately owned land, of which 138.7 hectare is farmland, 47 residential housing units, and 71,852 perennial crops and other trees. The impacts of the Gibe III-Sodo transmission line include 192 households, 129 hectares of farmland and 26,892 perennial crops and other trees. This number seems quite manageable as the benefits are more than the expected loss, as there is already a pre-planned roadmap for their resettlement.

Resettlements with implementation cost 2,242,278.75 USD and compensation payments with a cost of 2,242,278.75 USD are mentioned as mitigating mechanism. According to EEPCo-Gibe IIIRAP (2009) EEPCo will make internal monitoring for the proper compensation and implementation of the resettlement action plan. Whereas, the Federal Environmental Agency will be responsible for the external monitoring focusing on the impact of the project on resettlement, income restorations, degree of satisfaction of re-settlers and compensation provision.

Public health Impacts

Health impacts are one of the most expected side effects of the project. As due to water logging Malaria or other water borne diseases may out break if no proper arrangements taken on time, may result in health hazards for the local people. Different official Government Gibe III hydroelectric project documents, on the other hand, acknowledged that the project areas' is susceptible to Waterborne, vector borne, infectious diseases, endemic malaria and other communicable diseases.

As it is indicated by the official government Gibe III Public Consultation and Disclosure Plan document (EEPCo, 2009) local officials in the project area have raised their concern on entry of large number of people to the project area in search of job opportunity may aggravate the expansion of HIV/AIDS and other sexually transmitted diseases to the local communities. Mitigation mechanism to the problem of HIV/AIDS and other sexually transmitted diseases of the construction site is needed to be enabled. The document also revealed that henceforth, a quality health service has been set up to provide health care to the construction employees. Awareness raising campaigns and prevention programs has also been planned for the construction workers and local communities (EEPCo, 2009).

Cultural, religious, historical and archaeological sites preservation

Evidences from the Lower Omo Valley pre-historic and Paleo-anthropological sites have provided a unique insight into the oldest known technical activities by pre-historic beings (UNESCO, 2008). The World Bank policy and principles issued that World Bank sponsored projects should be consulted by local people, scientific institutions and NGOs and these consultations should ensure that the project will not affect 'cultural property' as sites having 
'archaeological, paleontological, historical, religious, and/or unique natural values (World Bank, 2012). Lower valley of the Omo River, where the Gibe III project located, is registered by UNESCO as one of the $9^{\text {th }}$ World Heritage sites of Ethiopia. The Public Consultation and Disclosure Plan Document of the government indicated that religious, cultural site relics and archaeological sites would not be affected by the project.

According to the investigation report the historical sites of the area known as King Ijajo Kella and King Halala Walls were found on both sides of the Omo River. The document stated that an additional archaeological impact assessment as well as the elongated stone walls in Wolayita and Dawro has been initiated by the Authority for the Research and Conservation of Cultural Heritage (ARCCH). The UNESCO heritage site is located far away from the downstream, Gibe III dam and reservoir area.

The report indicated that there are no visible archaeological remains of scientific, cultural, public, economic, ethnic and historic significance. However, the document indicated a "Chance Find" protocol has been prepared to cover any unexpected findings.

\section{Impacts on environments and natural resources}

Environment is the most important aspects for any community and their development as it covers the whole resources on which the community depends for the subsistence and sustenance.

\section{Environmental aspects}

Environmental aspects are the most important as it is straight related with the ecology and food availability of the people living in a geographical area, especially the concerns have been raised that how the sideeffects of the project can be managed and before the situation deteriorates how it can be sensitized among the people as well concerned officials and the media. On the negative side, large hydropower dams flood occupy a major proportion of the land available. And also, large dams alter the natural flow of rivers and cause problems with migrating fish. Other fish that spawn in moving water find little water flow in areas impounded by dams (Avery, 2012).

Hydroelectric dams can produce significant amounts of carbon dioxide and methane. But, Carbon emissions vary from dam to dam (IR, 2010). Forests and plant life are important, sucking Carbon dioxide from the air in the process of photosynthesis. Forests are, therefore, important to fight against global warming. Cutting down the trees to make room for dams and their infrastructure may harm to the environment potentially. The ESIS impact assessment focuses on impacts on natural vegetation, impacts on protected areas, impacts on wildlife resources and other privately owned assets which are as under:

Impact on natural végétations

The Gibe III, Environment Social Impact Study (ESIS) document stated that construction of dam and reservoir area will cause the loss of woodland grassland on the hill slopes of the valley and narrow riparian vegetation along the river and streams. However, to compensate this loss the document indicates that an estimated 60,000 ha of land around the reservoir will be developed as buffer area and it is expected to support the bio-diversity conservation by enhancing the biological value of the area.

Impact on protected areas

The lower Omo valley consists of National Parks, Wildlife Reserves, and National Forest Priority Areas. The ESIS document showed that the reservoir area is not located close to any of these nationally protected areas like national parks or wildlife sanctuaries reserves. It also indicates that there is no endangerment of endemic or rare species in the impounded areas.

Impact on wildlife resource

According to Gibe III, ESIS document the project area harbors only limited number of wildlife species. Therefore, the document goes on stating that there may not be a potential harm by the project to any such things.

Impacts on recession agriculture and grazing resources

Downstream farmers cultivate the river's banks after the annual flood, a practice known as flood retreat cultivation. The annual flood also supports the renewal of grazing lands for herders, and swamps on the floodplain and favors fish breeding. The construction of reservoir dam may hamper these traditional cultivation systems.

The downstream environmental assessment in this regards indicates that to satisfy the demand for traditional recession agriculture, dry season grazing and fishery resources, more water will be released and artificial flooding will be created on the land bordering the Omo River. These controlled floods will allow maintaining the required environmental flows even during the drought years. Therefore, the project has strong alternative arrangement systems. 
However, the environmental and social impact assessment document do not indicate the number of months or days the artificial flooding is practiced. IR (2010) in its report estimates that the artificial flooding lasts only for ten days. The organization argued that the artificial flooding cannot reach through all the areas like annual flooding, and which may likely to affect as shortage of agricultural productivity. The organization argued that the artificial flood would also depend on the goodwill of the dam operator which would create a conflict of interest. Even if implemented, the IR says that the artificial flood is not enough to maintain the local ecology, livelihoods as well as the economy. IR (2010) report on the Gibe III project have same opinion and states that, as the dam deteriorates traditional resources which may cause latent tension among the local communities may cause conflicts among local ethnic groups.

On the contrary to the claim of IR the Gibe III, ESIS report states that an annual audit for the same by an independent audit firm would be ensured and not only this, the recommendations also will be followed (EEPCo/Gibe III -ESIS, 2009). IR further argues that the government of Ethiopia is exploring the Gibe III area for oil and minerals and planning large-scale agricultural and bio-fuel schemes, which could further cause conflicts over traditional land and water resources. According to the available sources, yet, such plans are not mentioned in any of the official documents of the government.

\section{Flood management}

According to the Gibe III, ESIS report the reservoir operation will regulate the flows in the Omo River downstream of the plant. Due to this there might be an increase in the flows even during the dry season and a reduction of the flows during the rainy season; which may affect the flow of the river and the flood situation may be managed by regulating the river flow.

The report further states that regulating the flow of the river is also beneficial for the local people to navigate throughout the year. A Kenyan NGO, Friends of Lake Turkana established to oppose the construction of Gibe III hydroelectric project, on the issue arguing that the Omo river provides $80 \%$ water to the Turkana's water, but the ESIS document did not mention the impact of the Gibe III project on the potential changes to the river flow, volume, and chemical balance or analysis of the impacts of reservoir evaporation rates to downstream volumes etc (Avery, 2010).

It seems that the power project has been the part of politics. Recently, a report by the African Study
Centre has warned against the project which might have no genuine reason as the governments' have already sought the alternative measures regarding the change in agricultural system or any adverse effect on pastoral structure for livelihood of the communities.) Ethiopian authorities argued that once the dam is built the total amount of water flowing to the lake will not change. But, the critics say that the impact of Gibe III on Lake Turkana is barely acknowledged in the project's impact assessment, and is dismissed with claims that the project will benefit, not harm, the lake (Friends of Lake Turkana, 2012).

Constitutional safeguards

Constitution provides the guideline to act or initiate any activity in its geographical area which may affect the resource or the people in its jurisdiction.

Ethiopian constitution article 44 states about the Environmental Rights of people and declares that "all persons are entitled to the right to live in a clean and healthy environment." Similarly Article 92 of the constitution is about Environmental Objectives which declares that "Government shall ensure that all Ethiopians live in a clean and healthy environment."

According to initial estimates programs and projects design shall not damage or destroy the environment and the constitution goes on saying that "Government and citizens have the duty to protect the environment."

Ethiopian environmental policy dictates that "any firm working in development endeavors need to conduct environmental impact assessments and should get approvals from the Ethiopian Environmental Authority."

And partners of the Gibe III project- the World Bank and African Development Bank, international financial institutions and international conventions and protocols signed by Ethiopia made environmental impact assessments as mandatory.

The official environment and social impact assessment document of EEPCo approved by Ethiopia's Environmental Protection Authority (EPA), was released in January 2009 indicated that 'the Gibe III hydroelectric project was commenced in accordance with the country's constitution and environmental policy. Therefore, key environmental impacts during the construction and operation and maintenance phases of the project have been identified."

An Italian NGO Campagna per la Riforma della Banca Mondiale (CRBM) on the contrary criticized the EPA documents for its poor preparation and late release (CRBM, 2008, IR: 2010). In line with this, a report from International Rivers (IR), an 
environmental and human rights organization based in California, United States of America also states it, as a deliberate violation of Ethiopian environmental law. IR also criticized for the late report release and construction of the project prior to conducting the impact assessment (IR, 2010).

In continuation to that, CRBM further indicated that the Environmental Protection Agency of Ethiopia, established in 2002, have under- resourced staff and hence, the agency cannot adequately resume its duty responsibly. The EEPCo/Gibe III -ESIS (2009) document, however, stated about the potential negative impacts of the proposed Gibe III hydropower Project on the physical, biological and socio-economic environment. It also identifies the benefit enhancement and recommended the mitigation measures that should be adopted to avoid or minimize potential adverse impacts. The impact assessment involved the major areas of the project such as dam, reservoir area and downstream lowers Omo valley.

\section{Discussion}

The Principles of community development involves several interrelated factors which jointly contribute to the community and show their impact in the linking and consistent way. Community development approaches to health promotion should seek to examine power relations and social change, use collective working, give attention to marginalized populations, have a commitment to equity and social justice (Chile, 2006).The hydroelectric project also deals with health concern of the local community in the Omo river area. It is already expected that increased economic activities and employment opportunities might be the "pull -factor for migrants. So, the people especially the marginalized may become vulnerable to several communicable and other infectious diseases including HIV/AIDS and Malaria.

Chile argues that community development as policy and the practice of social change through organizing, coordinating and initiating activities that enhance the wellbeing of individuals, groups and communities is more than 'pedagogy of the oppressed. 'And, therefore, he said community development cannot be conceptualized simply in terms of 'resistance'. It is a holistic process of transformation encompassing socio-economic, political, cultural, environmental and spiritual dimensions (Chile, 2006). The Gilgel Gibe III hydroelectric power project in this regard expected to bring holistic change in the livelihood of the people living in and around the project. Few months back one of the researchers have visited that area and held an informal discussion with the local people. It is observed that there are mixed reaction by the people; some were found very excited due to implementation of the project. A person stated that:

We spent our all life amid misery and dark now at least we can die with peace after seeing that no more our future generation is likely to suffer the way we suffered.

There were very few who were criticizing the project on the cultural ground - an elderly person from the nearby area said that:"“

Everything is good about project but it may affect our cultural identity and cause erosion of our year old culture and tradition."

Livelihood and income opportunities of course were the concern of the local community. A young a person who never went out from the area, he always earned his livelihood from the local area only, stated that: "

We are more concerned with our occupation, if it gives us chance to earn a comfortable subsistence why shall we go against it? Let other people say what they are saying, but we know that we have been suffering a lot. We can see that there are some markets like situation developed and we can exchange our services or whatever we have to do so. But we do not favor if people from other area encroach our opportunities."

The dam site will create a large artificial lake that will provide different environmental and ecological niches for diverse fisheries and crocodile development farming, recreation establishments, irrigation development plans and navigation which might straight benefit to the neighboring communities during market days and other social occasions. On the other hand, the development of infrastructures also is the probable economic benefits of the project in enhancing trade and commerce among the local communities. Interconnectedness of the various communities is also one of the observable impacts. Earlier due to lack of infrastructure (road and transport facilities, water for daily use including drinking water, community health centers etc. ) was almost a most difficult task for people to sustain. Due to their coping management systems with the natural surroundings, made their life to live in the harsh situations. The infrastructure development may provide a chance to negotiate and minimize the conflict amongst the different ethnic groups.

People living in a society are the major capital for growth of economy, they are the only tool which is more vital and works powerfully, 'Social capital' which is as a tool to help "repair the social fabric of society" (Gillies 1997:3). A second year student of Public Administration Management (PADM) at 
Mekelle University states who comes from the Omo river area states that:

"We have been living in the very harsh conditions through our life, I had never imagined that our area will change so fast, believe me we had no electric lamp for many years in our area. Still, it is a mystery; people in our area are so shy and humble in nature, that they would have never demanded if the government would have not taken decision to put them in light."

Elaborating the discussion another friend of him from the same area and same department says that;"

Can you imagine how many dreams we are now weaving every day? It will definite change the fate of our people, at least now we can hope to live in light we spent our entire life in dark."

Historically, the Omo river valley and the population around have been isolated due to lack of several things such as- income generation, resource mobilization and providing them facility like the mainland due to its location and other geographical reasons. And as we have already discussed that agriculture type is semi arid and agro- pastoralism- as a main occupation, therefore, the food security, fuel and energy has always been a major obstacle. The ethnic groups of the area had developed their own unique type of system to cope with the situation. The coming up of the power project would open a new door for the people in many ways. Hydroelectric power projects may thrust to the industrialization process in the project proposed area in Ethiopia which can contribute positively to the developing economy as well as generate the employment opportunities which may rise to the community development. The project from its inception is generating employment opportunities during the construction and in the form of off-the-farm employment opportunities and development in different sectors including revolutionizing the commercial and trade industry during the operation of the project.

Majority of the respondents who come from same area but study at various Departments at Mekelle University emphasized their basic need to live in light as top priority than economic benefits. A third year student from Sociology Department states that:

"Economic benefits or income generation is another aspect and second most important part of the project. First, survival is the most important how one can sustain without energy, if one accessed to energy he will generate employment opportunities himself."

Another respondent from the same area studies at Accounting Department was asked on people from other area would immigrate to project area may increase the burden on local resources. He states that:
"No matter we will manage it, so shall we live in dark to avoid such situation? No way, we are happy. Now people are migrating everywhere from one place to another; therefore it is not an issue."

The sociological impact of the environment and their potential hazards has been investigated already by the researchers (Mishra et al, 2010). Society itself is an integral part of the total environment where an individual performs all his activates. The researchers have warned about the impact of the industrial pollution due to environmental hazards but that can potentially be managed by developing the industrial waste management and other mitigation mechanisms (Mishra, 1999). Ecological impact assessment can be carried out in order to know the regular impact on the area and its natural environment as ecology decides the correlation between the various natural components and the species. Due to rising energy demands and abundant untapped potentials especially the water resources and, comparatively low production cost hydropower projects are rapidly increasing in the Afrotropics. Finer in his study in Amazon region investigated the potential ecological impacts of the hydroelectric power projects (Finer 2012). This impact is of the similar importance in Ethiopian context as well. The downstream environmental assessment in this regards indicate that to satisfy the demand for traditional recession agriculture, dry season grazing and fishery resources, seasonally more water will be released and artificial flooding will be created on the land bordering the Omo River and an estimated 60,000 ha of land around the reservoir will be developed as buffer area and it is expected to support the bio-diversity conservation by enhancing the biological value of the area.

\section{Conclusion}

These findings have three important implications for policy. First, as regional governments promote hydropower as the centerpiece of long-term energy plans for the community development as well as growth of revenue, a shift towards more strategically planned community development initiatives to eradicate the poverty and food security, multi-factor planning and assessment of the executed action in order to fathom the overall impact which could reduce potentially profound ecological impacts. The study had been divided into three parts to examine the overall impact on the community development and how it is likely to affect the population in its periphery- viz. socio-economic development, environment and natural resource and constitutional rights of the people as well as whether the projects fulfills the criterion made under law. It is found that 
the experience from the other similar projects from the past which were installed in Ethiopia as well as other countries have been well utilized by the officials involved in the project. So, there is little or no chance of flop or any sorts of failure, but its failure parts also have been well addressed in it by building water reservoir and developing a green land area where trees and forests to maintain ecological balance. Aquatic farming also has been planed such as fisheries and crocodile farming. Tourism has been a kind of popular area in the site location as it is already on the world map by the UNESCO and the Ethiopian government. Moreover, the artificial lake and proper road map have been planned to make the project a success and add to its tourist attractions. On the other hand, international consultancy services which have expertise in handling the similar projects have also been hired for their suggestions. It is of worth to mention here that transportation and connectivity has been a major hurdle in development , but it is remarkable to state that in the area now three tear transport plan is soon likely to be in action i.e., water, road and traditional routes.

Ethiopian constitution is one of the most vital and vigilant constitutions of the horn of Africa, therefore, all precautions and aftermath have already been put in place before framing the project polices. Through afforestation policies of the project, it is observed that ecological aspects have been more strengthened by converting the dry areas into cultivable and greensands. Ethiopia has now well experience and efficient in handling in similar projects ,for example, Gilgel Gibe-I \& II, Tekeze, Tana Belse and the ongoing Renaissance Dam. For marginalized and most poor people are given special privilege under the project according to the government policies. And of course the participation of local communities at large will decide the success of the project. Most importantly, buyers of the electric produced are already in the queue so there is almost very meager chance of any type of financial risk.

\section{Recommendation}

Though, the upcoming hydroelectric power project has comprised all aspects related to the people area and the community development in its program since the inception, but further studies related to the impacts and policy implementation suggested to be carried out to assess and know the exact situation. Study based on primary data contacting the opinion of the people also might be helpful in justifying the project and its impact on the people. Further, more studies on various dimensions such as health, culture, conflict, gender and livelihood diversifications are recommended, as till date no single study based on primary data source have been conducted on the project area .Research studies may contribute in guiding and monitoring the government and other welfare associations working on the community development in the area.

\section{Acknowledgement}

Authors are highly thankful to the Department of Sociology, Mekelle University, Ethiopia, for granting all supports that we needed in completion of the work, otherwise would have never been possible. We also extend our sincere thankfulness to the anonymous reviewers for their expert comments and suggestions which of course increased the academic value of the research article.

\section{Notes}

1 The Project is purposed to achieve the Millennium Development Goals by 2015 in poor agricultural regions through science-based, community interventions across the sectors of agriculture, nutrition, health, water and sanitation, energy, infrastructure and ICT, and business enterprise development.

2 Zone is the bigger most administrative Unit in the Ethiopian State divisional structure

3 Woreda is the second most administrative unit the Ethiopian State divisional structure

4 Kebele is the lower most administrative Unit in the Ethiopian State divisional structure.

\section{References}

Anaya, James (2010). Ethiopia: Situation of the Gilgel Gibe III hydroelectric project on the Omo River. United Nations. Retrieved from http://unsr.jamesanaya.org/index.php.

Avery, S., (2012). Lake Turakan and the lower Omo: Hydrological impacts of major dam and irrigation developments. African Study Centre, University of Oxford. Vol. I-Report. PP.1-18

Batliwala, S., Reddy, A.K.N. (2003). Energy for women and women for energy (engendering energy and empowering women). Energy for Sustainable Development VII(3), 33-43.

Bekele, Almaz (2005). Electricity shortages and their impact on large- and medium-scale manufacturing industries in Ethiopia, Energy Research Centre, University of Cape Town. Retrieved from http://Active.Cput.Ac.Za/Energy/Web/Icue/Papers/Pdf

Bergsten, Peter (2006). Audit of social and economic impacts of the Rio Estí Hydroelectric Project, Panama. Arbetsgruppen för Tropisk Ekologi Uppsala University, Sweden Committee of Tropical Ecology.

Campagna per la Riforma Della Banca Mondiale (2008).The Gilgel Gibe Affairs, An analysis of the Gilgel Gibe hydroelectric projects in Ethiopia. Retrieved from http://www.crbm.org/modules.

Cerenea, M. Michael (1984). Role of sociological knowledge in planned rural development, Sociologia Ruralis, XXIV-3/4, 185-201.

Cernea, Michael (2004). Social impacts and social risks in hydropower programs: Preemptive planning and counter-risk measures. George Washington University 6113 Robinwood Rd., Bethesda, MD. 20817. USA.

Chile, Love (2006). The historical context of community development in Aotearoa New Zealand. Community Development Journal. 41,(4) 407-42. 
Dutt, G.S. (1994). Illumination and sustainable development. Part I: technology and economics. Energy for Sustainable Development, I(1), 23-35.

Edkins,A., Eapen, S., kaluwile, F., Nair,G., Modi,V., (2010). Offgrid energy services for the poor: Introducing LED lighting in the Millennium Villages Project in Malawi, 38(2),10871097.

Ethiopian Electric Power Corporation (2009). Gibe III - Public Consultation and Disclosure Plan.

Energy consumers edge (2007). Pros and cons of hydropower dams not so free energy from flowing water. Retrieved from http://www.Energy-Consumers-Edge.Com/Html.

Ethiopian Electric Power Corporation (2009). Gibe III Environmental and Social Impact Assessment.

Ethiopian Electric Power Corporation (2009). Environmental monitoring unit /EMU environmental and social impact.

Ethiopian Electric Power Corporation (2009). Gibe III Resettlement action plan dam and reservoir area, Vol I.

Ethiopian Electric Power Corporation (2009). Gibe III Resettlement action Plan Dam and Reservoir area, Vol II.

Federal Democratic Republic of Ethiopia Constitution (FDRE, 1995).

Fiends of Lake Turkana (2012). Challenges from lake Turkana community. Retrieved from http://www.friendsoflaketurkana.org/folt-news.

Fiends of Lake Turkana (2012). New study reveals likely full impact of gibe 3 and irrigation on Lake Turkana and Omo River. Retrieved from: http://www.friendsoflaketurkana.org /folt-news.

Finer M, Jenkins CN (2012). Proliferation of hydroelectric dams in the Andean amazon and implications for Andes-amazon connectivity. PLoS ONE 7(4): e35126. doi:10.1371/ journal.pone.0035126.

Foundation of water and energy education (2010). How a hydroelectric project can affect a river? Retrieved from http://www.fwee.org/hpar.html.

Gaillard, Roger M. (2008). Regional integration of power systems: A tool to reduce energy poverty and to accelerate economic growth. African Development Bank, Workshop on Energy Poverty in Africa, Abuja Nigeria.

Gillies, P. (1997). Social capital: Recognizing the value of society, health lines magazine, Issue 45 (September 1997) cited in Community Development and Empowerment: in ThompsonFawcett,M and Freeman, C. (eds) Living Together: Towards inclusive communities, Dunedin, University of Otago Press: pp.207-227.

Global energy observatory (2012). Gilgel Gibe III hydroelectric power project Ethiopia. Retrieved from http://globalenergyobservatory.org/geoid/43184.

International energy agency (2009). Access to electricity. Retrieved from http://www.worldenergyoutlook.org/ resources/energydevelopment/accesstoelectricity/.

International rivers organization (2010). Ethiopia's Gibe 3 Dam; Sowing Hunger and conflict. Retrieved from www.nowaternlife.org.

Karekezi, S., Kimani, J. (2004). Have power sector reforms increased access to electricity among the poor in East Africa? Energy for Sustainable Development VIII(4), 10-25.

Laxmi, V., Parikh, J., Karmakar, S., Dabrase, P. (2003). Household energy, women's hardship, and health impacts in rural Rajasthan, India: need for sustainable energy solutions. Energy for Sustainable Development VII (1),50-68.

Martin Looney (1995). Social problems, community trauma and Hydro project impacts Canadian Journal of Native Studies, 1995- loki3.brandonu.ca.

Mills, E. (2005). The specter of fuel-based lighting, Science 308(5726), 1263-1264.

Mills, E., Jacobson, A. (2007). The off-grid lighting market in western Kenya: LED Alternatives and consumer preferences in a millennium development village. Lumina Project
TechnicalReport\#2. Retrieved from http: //light. lbl.gov/pubs/tr/Lumina-TR2.pdfS.

Mishra, S., Shukla, K. K., Tiwari, S. Singh, A.K. (2010). Some sociological implications of environmental hazards. International Journal of Ecological Economics and Statistics. $17(10)$.

Mishra, S. (1999). Environmental hazards due to industrial pollution. Unpublished Ph.D. thesis, available at Central Library Benares Hindu University, Varanasi, India.

McCull, Patrick Y (2003). Big dams, big trouble. New Internationalists. Retrieved from http://Findarticles.Com.

Modi, V., S. McDade, D. Lallement, J. Saghir (2006). Energy services for the millennium development goals. New York: Energy Sector Management Assistance Program, United Nations Development Program, UN Millennium Project, and World Bank.

Najam, Adil \& Cutler J. Cleveland (2008). Energy and sustainable development at global environmental summits. In: Encyclopedia of Earth. Eds. Cutler J. Cleveland (Washington, D.C.: Environmental information coalition, national council for science and the environment. Retrieved from http://www.Eoearth.Org/Article/Energy_And_Sustain able_ Development_At_Global_Environmental_Summits.

Peon, R., Doluweera, G., Platonova, I., Irvine-Halliday, D., IrvineHalliday, G. (2005). Solid-state lighting for the developing world - the only solution. Proceedings of SPIE 5941, 59410N.

Rodrigue, Jean-Paul and Comtois, Claude (2013).Transportation and energy. The geography of transport system .department of Global studies and Geography, Hofstra University, New York ,USA. Retrieved from http://people.hofstra.edu/ geotrans/eng/c.html.

Rosenberg D M, Berkes, F.,Bodaly, R.A., Hecky, R. E., Kelly, C A., Rudd, J. W.M., (1997). Large-scale impacts of hydroelectric development. Environmental Reviews, 1997, 5(1): 27-54, doi:10.1139/a97-001.

Saghir, J. (2005). Energy and poverty: myths, links, and policy issues. Energy Working Notes, no. 4. Energy and Mining Sector Board, World Bank, Washington D.C.

Sanchez, P.A., Palm, C.A., Sachs, J.D., Denning, G.L., Flor, R., Harawa, J., Jama, B., ...., Zamba, C. (2007). The African millennium villages. Proceedings of the National Academy of Sciences 104 (43), 16775-16780.

Sanchez, P.A., Denning, G.L., Nziguheba, G. (2009). The African green revolution moves forward. Food Security 1 (1), 37-44.

Shahi, R.V. (2003). Hydroelectric projects development: Challenges and Response. FOR valedictory session in international conference on large dams (ICOLD) at Montreal, June 17-20. Retrieved from w.w.w.powermin.nic.in/whats_ new/pdf/icold.doc.

Smil,V.(2007). Energy at the crossroads: Global perspectives and uncertainties, MIT Press.

Smil,V.(2007). Energy in nature and Society. The MIT press.

Survival International (n.d). Retrieved from: http://www.survivalinternational.org

UNESCO Courrier (2008). Lower Valley of the Omo, Number 8. Retrieved from http://whc.unesco.org/en/list/17.

Van der Plas, R., de Graaff, A.B.(1988). A comparison of lamps for domestic lighting in developing countries. World Bank Industry and Energy Department Working Paper, Energy Series Paper no.6.World Bank, Washington, D.C. Retrieved from: /http://www-wds.worldbank.org/external/default/ PDF/multi_page.pdfs.

World Bank (2012). Electricity program expands access to energy for Ethiopians with support from the World Bank. Retrieved from http://www.worldbank.org.electricity-programexpands-access-energy-for-ethiopians-with-support-fromworld-bank.

World Commission on Dams (2000). Dams and development: A new framework for decision-making. Retrieved from http://www.world_commission_on_dams_final_report.pdf. 


\section{Appendixes}

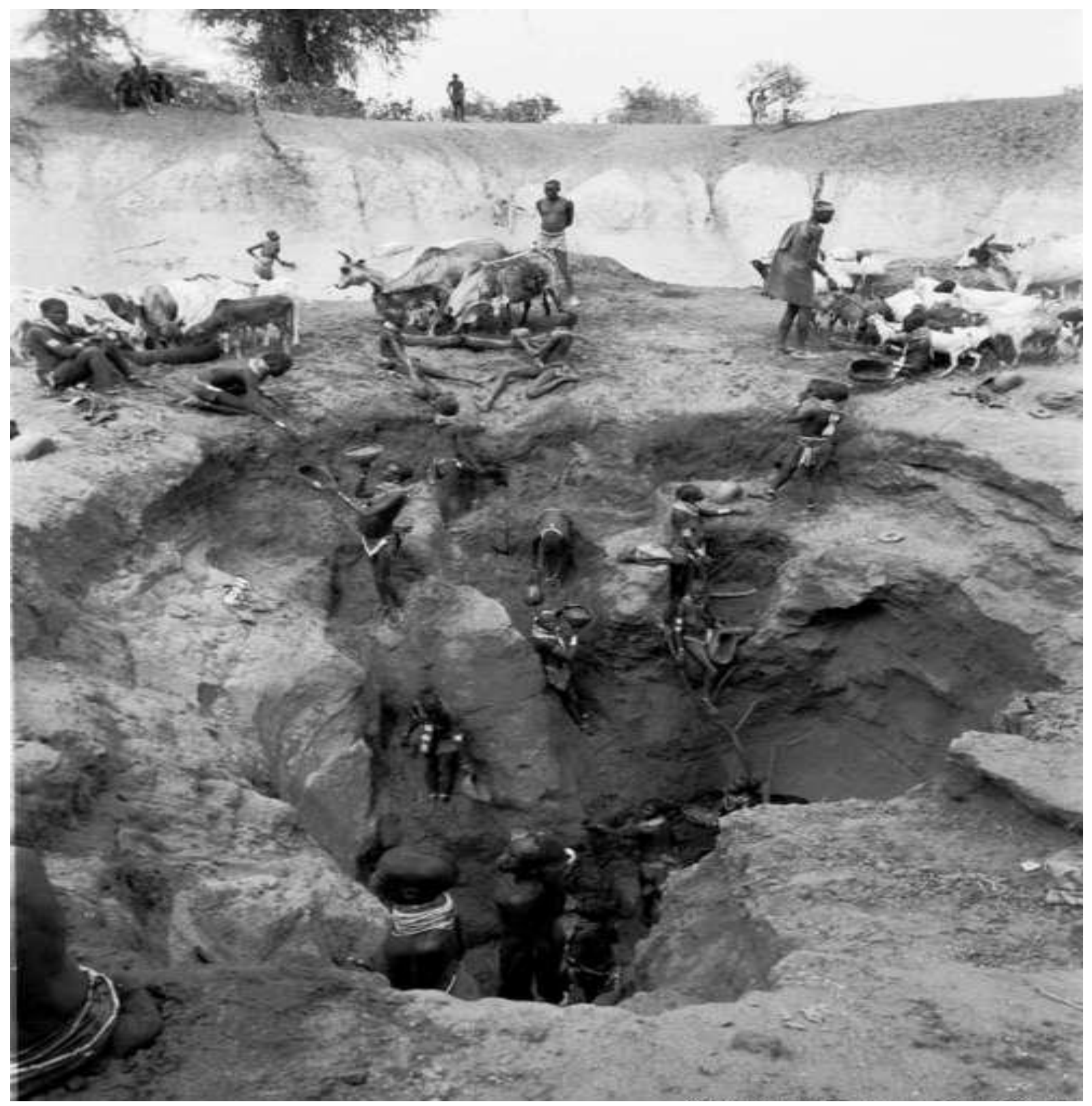

Figure 2. Extracting drinking water during dry season is not an easy for Nyangatom community dig deep well into the land, Ethiopia. Source: Survival International. 


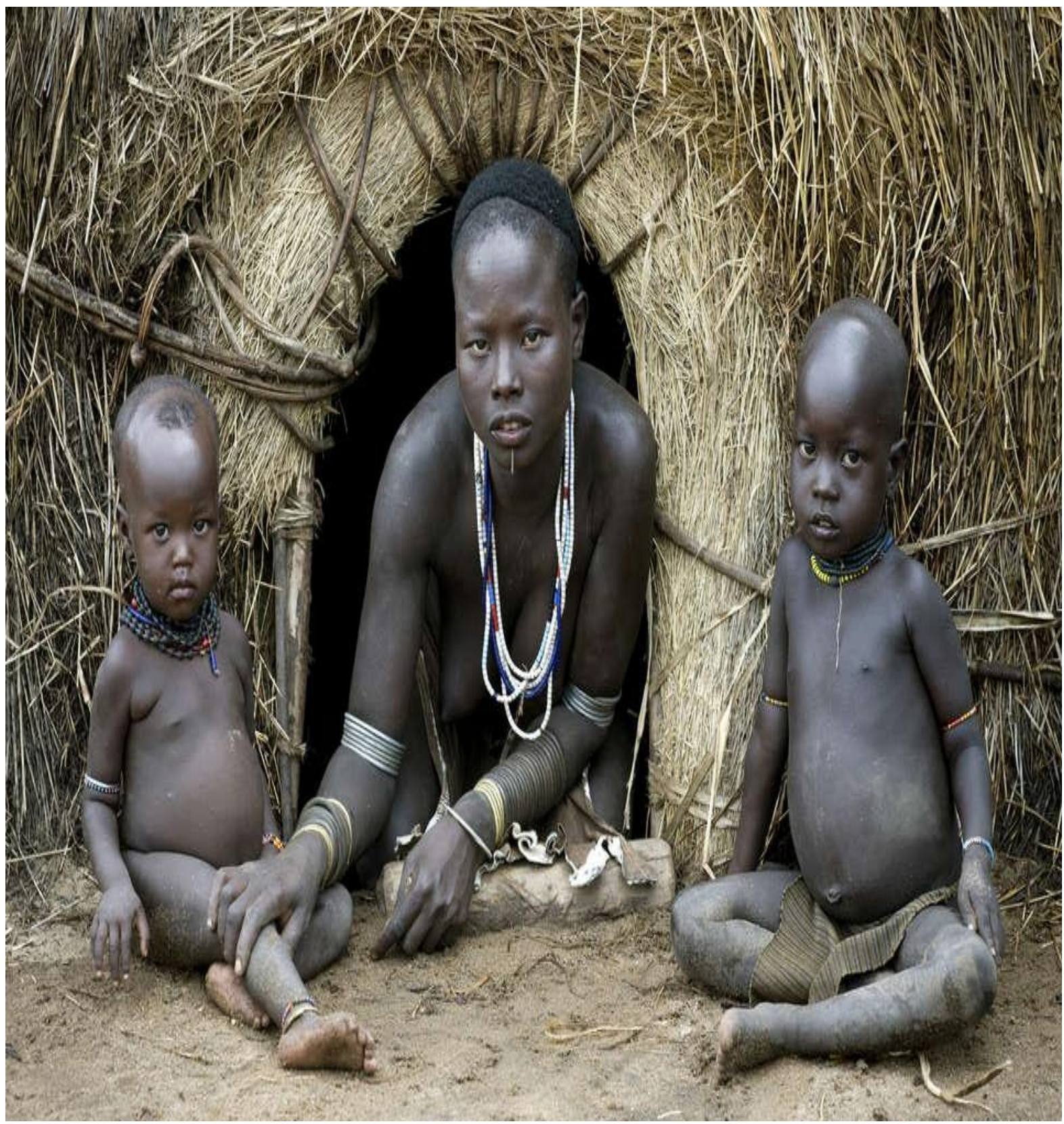

Figure 3. A dwelling of the Karo community, Bank of Omo River, Ethiopia. Source: Survival International. 


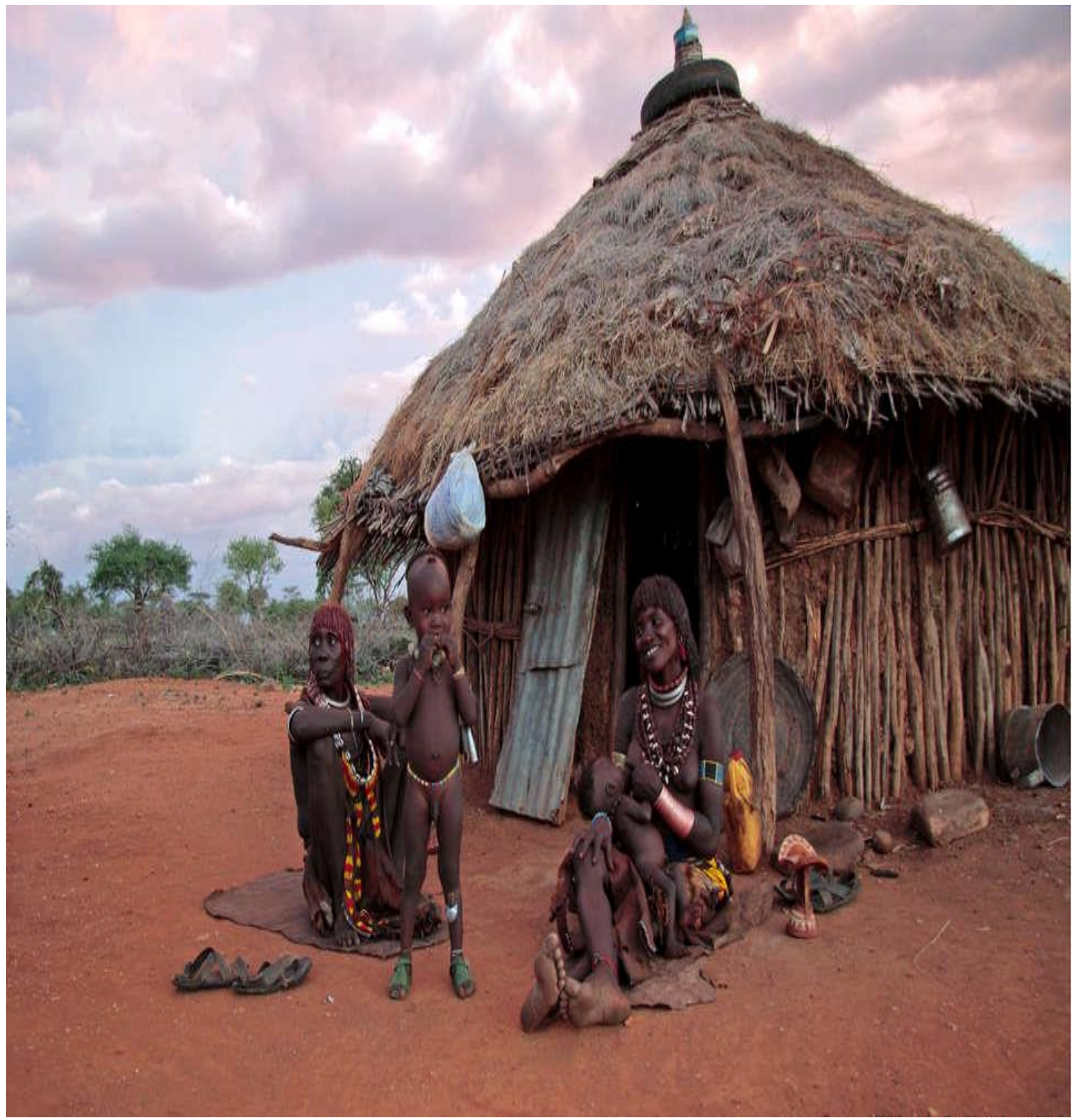

Figure 4. Amid agony and pleasure: A family of Hamar community, Omo river valley, Ethiopia. Source: Survival International. 